\title{
NUCLEAR COUNTRY
}





\section{NUCLEAR COUNTRY}

\section{THE ORIGINS OF \\ THE RURAL NEW RIGHT}

Catherine McNicol Stock

$\overline{\text { PENN }}$

UNIVERSITY OF PENNSYLVANIA PRESS

PHILADELPHIA 
A volume in the Haney Foundation Series, established in 1961 with the generous support of Dr. John Louis Haney.

Copyright (C) 2020 University of Pennsylvania Press

All rights reserved. Except for brief quotations used for purposes of review or scholarly citation, none of this book may be reproduced in any form by any means without written permission from the publisher.

\author{
Published by \\ University of Pennsylvania Press \\ Philadelphia, Pennsylvania 19104-4112 \\ www.upenn.edu/pennpress \\ Printed in the United States of America \\ on acid-free paper
}

13579108642

A Cataloging-in-Publication record is available from the Library of Congress ISBN 978-0-8122-5245-3 
For PJ 
